\title{
PENDIDIKAN DAN PENILAIAN KARAKTER DI SEKOLAH MENENGAH KEJURUAN
}

\author{
Edy Supriyadi \\ FT Universitas Negeri Yogyakarta (e-mail: edy_via@yahoo.com; HP: 087839000210)
}

\begin{abstract}
Character Education and its Assessment in Vocational High Schools. Character education is a process of helping people to develop good characters, such as honesty, responsibility, compassion, and self-respect. Character education at school aims to build the student and staff characters and to develop the school culture. The assessment of character education covers that of student and staff characters and the school culture. The assessment of student character can be conducted through classroom-based assessment by teachers. In addition, civic education and religion teachers are supposed to conduct the assessment of student character more thoroughly. The assessment of staff character should be conducted by a school internal team. The school culture may be assessed by a provincial external team. The results of assessment are used to make decisions of student grade promotion and graduation and to improve a character education program.
\end{abstract}

Keywords: education, character education

\section{PENDAHULUAN}

Pendidikan memiliki fungsi sangat penting dalam pembentukan karakter dan budaya bangsa. Dalam Undang-Undang No 20 Tahun 2003 Tentang Sistem Pendidikan Nasional pada Pasal 3 disebutkan bahwa pendidikan nasional berfungsi mengembangkan kemampuan dan membentuk karakter serta peradaban bangsa yang bermartabat dalam rangka mencerdaskan kehidupan bangsa. Selanjutnya disebutkan bahwa pendidikan nasional bertujuan untuk berkembangnya potensi peserta didik agar menjadi manusia yang beriman dan bertakwa kepada Tuhan Yang Maha Esa, berakhlak mulia, sehat, berilmu, cakap, kreatif, mandiri, dan menjadi warga negara yang demokratis serta bertanggung jawab. Berkaitan dengan hal tersebut, Pendidikan di setiap jenjang, termasuk Sekolah Menengah Kejuruan (SMK) harus diselenggarakan secara sistematis guna mencapai tujuan pendidikan nasional tersebut. Melalui pendidikan di SMK diharapkan dapat dihasilkan lulusan yang memiliki kompetensi memadai dan berkarakter mulia.

Penelitian diHarvard University Amerika Serikat (Rao, 2010:2) menunjukkan bahwa kesuksesan seseorang tidak ditentukan semata-mata oleh pengetahuan dan kemampuan teknis (hard skill) saja, tetapi lebih oleh kemampuan mengelola diri dan orang lain (soft skill). Penelitian tersebutmengungkapkan, kesuksesan hanya ditentukan sekitar 20 persen oleh hard skill dan sisanya 80 persen oleh soft skill. Orang-orang tersukses di dunia bisa berhasil dikarenakan lebih banyak didukung kemampuan soft skill daripada hard skill. 
Hasil beberapa penelitian (Suyanto, 2009:2) menunjukkan bahwa kecerdasan emosi anak sangat berpengaruh terhadap keberhasilan di sekolah. Hasil penelitian tersebut juga mengungkapkan bahwa terdapat sederet faktor risiko penyebab kegagalan anak di sekolah. Faktor-faktor resiko yang disebutkan ternyata bukan terletak pada kecerdasan otak, tetapi pada karakter. Anak-anak yang mempunyai masalah dalam kecerdasan emosi akan mengalami kesulitan belajar, bergaul, dan tidak dapat mengontrol emosi. Anakanak yang bermasalah ini sudah dapat dilihat sejak usia pra-sekolah, dan kalau tidak ditangani akan terbawa sampai usia dewasa. Sebaliknya, para remaja yang berkarakter akan terhindar dari masalah-masalah umum yang dihadapi oleh remaja seperti kenakalan, tawuran, narkoba, miras, dan sebagainya. Hal ini mengisyaratkan bahwa mutu pendidikan yang mengarah pada pembentukan karakter peserta didik sangat penting untuk ditingkatkan.

Karakter merupakan suatu pola perilaku seseorang (Ryan and Bohlin, 1999:6). Orang yang berkarakter baik memiliki pemahaman tentang kebaikan, menyukai kebaikan, dan mengerjakan kebaikan tersebut. Orang yang perilakunya sesuai dengan kaidah moral disebut dengan berkarakter mulia. Karakter adalah bawaan, hati, jiwa, kepribadian, budi pekerti, perilaku, personalitas, sifat, tabiat, temperamen, dan watak. Berkarakter adalah berkepribadian, berperilaku, bersifat, bertabiat, dan berwatak. Dalam pendidikan karakter di sekolah, semua pemangku kepentingan harus dilibatkan. Seluruh komponen pendidikan, yang meliputi kurikulum, proses pembelajaran, penilaian, pengelolaan sekolah, pelaksanaan aktivi- tas atau kegiatan ko-kurikuler, pemberdayaan sarana prasarana, pembiayaan, dan komponen lainnya harus bernuansa pembentukan karakter siswa.

Terlepas dari berbagai kekurangan dalam praktik pendidikan di Indonesia, apabila dilihat dari standar nasional pendidikan yang menjadi acuan pengembangan Kurikulum Tingkat Satuan Pendidikan (KTSP) dan implementasi pembelajaran dan penilaian di sekolah, tujuan pendidikan di SMK sebenarnya dapat dicapai dengan baik. Pembinaan karakter juga termasuk dalam materi yang harus diajarkan dan dikuasai serta direalisasikan oleh peserta didik dalam kehidupan sehari-hari. Permasalahannya, pendidikan karakter di sekolah selama ini baru menyentuh pada tingkatan pengenalan norma atau nilai-nilai, belum pada tingkatan internalisasi dan tindakan nyata dalam kehidupan sehari-hari. Di samping itu, penilaian hasil belajar yang mengarah pada aspek karakter selama ini belum dilakukan secara memadai.

Permasalahan yang paling sering diperdebatkan dalam pendidikan karakter adalah penilaian. Pendidikan karakter seringkali dianggap sebagai bidang yang sulit untuk diukur, dinilai, dan dievaluasi. Hal ini berkenaan dengan hasil akhir dari pendidikan karakter yang berupa tindakan moral, bukan berupa pemikiran atau gerakan yang dengan mudah dapat dinilai melalui kemampuan menulis jawaban dan mempraktikkan sebuah keterampilanyang kemudian diakumulasikan dalam bentuk angka. Masalah penilaian sering dikaitkan dengan tujuan pendidikan karakter. Apakah penilaian harus dikaitkan dengan kenaikan kelas atau kelulusan, seperti yang selama ini dianjurkan 
pemerintah. Jika ya, bagaimana teknik, instrumen, pelaksanaan, dan pemanfaatannya. Hal ini mengisyaratkan bahwa sistem pendidikan karakter di SMK, terutama pada aspek penilaian sangat mendesak untuk disempurnakan.

\section{Penyelenggaraan Pendidikan Karakter di SMK}

Sekolah Menengah Kejuruan (SMK) adalah satuan pendidikan pada jalur pendidikan formal jenjang menengah yang mempersiapkan lulusannya memasuki dunia kerja, yang mampu mengembangkan dirinya di kemudian hari. Peningkatan mutu SMK pada dasarnya adalah upaya untuk lebih mendekatkan ukuran kompetensi lulusan dengan ukuran kompetensi yang dipersyaratkan oleh dunia kerja. Pendidikan di SMK diharapkan mampu memberikan bekal kemampuan yang utuh dan memadai sehingga tamatannya dapat menerapkan kemampuannya di dunia kerja.

Standar Kompetensi Lulusan SMK/ MAK menurut Permendiknas No. 23 Tahun 2006 tentang Standar Kompetensi Lulusan yang berkaitan dengan karakter antara lain mencakup: (1) berperilaku sesuai dengan ajaran agama yang dianut sesuai dengan perkembangan remaja; (2) mengembangkan diri secara optimal dengan memanfaatkan kelebihan diri serta memperbaiki kekurangannya; (3) menunjukkan sikap percaya diri dan bertanggung jawab atas perilaku, perbuatan, dan pekerjaannya;(4) berpartisipasi dalam penegakan aturan-aturan sosial; (5) menghargai keberagaman agama, bangsa, su$\mathrm{ku}$, ras, dan golongan sosial ekonomi dalam lingkup global; (6) membangun dan menerapkan informasi dan pengetahuan secara logis, kritis, kreatif, dan inovatif; (7) menunjukkan kemampuan berpikir logis, kritis, kreatif, dan inovatif dalam pengambilan keputusan; (8) menunjukkan kemampuan mengembangkan budaya belajar untuk pemberdayaan diri, dan serangkaian kompetensi serta nilai karakter terkait lainnya. Berkaitan dengan Standar Kompetensi Lulusan SMK tersebut, pendidikan karakter harus dirancang dan diselenggarakan dengan baik agar lulusan SMK memiliki kompetensi dan karakter mulia seperti yang diharapkan. Rancangan pendidikan karakter perlu dilakukan secara terpadu dalam pengembangan Kurikulum Tingkat Satuan Pendidikan (KTSP).

KTSP adalah kurikulum operasional yang disusun dan dilaksanakan oleh masing-masing satuan pendidikan (Peraturan Pemerintah No. 19 Tahun 2005, Pasal 1). KTSP SMK disusun bersamasama oleh Guru, komite sekolah/yayasan, konselor (Guru BK/BP), industri/dunia usaha, asosiasi profesi, dengan kepala sekolah sebagai ketua merangkap anggota, dan disupervisi oleh Dinas Pendidikan Kabupaten/Kota. KTSP disusun sebagai pedoman penyelenggaraan kegiatan pembelajaran untuk mencapai tujuan pendidikan di tingkat satuan pendidikan. Mata pelajaran-mata pelajaran yang ada pada struktur dan muatan kurikulum KTSP SMKterdiriatas tiga kelompok, yaitu program normatif, adaptif, dan produktif.

Kelompok program normatif adalah mata pelajaran yang dialokasikan secara tetap yang meliputi Pendidikan Agama, Pendidikan Kewarganegaraan, Bahasa Indonesia, Pendidikan Jasmani Olahraga dan Kesehatan, dan Seni Budaya. Kelompok program adaptif terdiri atas mata 
pelajaran Bahasa Inggris, Matematika, Ilmu Pengetahuan Alam, Ilmu Pengetahuan Ssosial, Keterampilan Komputer \& Pengelolaan Informasi, dan Kewirausahaan. Kelompok program produktif terdiri atas sejumlah mata pelajaran yang dikelompokkan dalam Dasar Kompetensi Kejuruan dan Kompetensi Kejuruan. Kelompok program adaptif dan produktif adalah mata pelajaran yang alokasi waktunya disesuaikan dengan kebutuhan Kompetensi Keahlian, dan dapat diselenggarakan dalam blok waktu atau alternatif lain (Depdiknas, 2008:7).

Program normatif berfungsi membentuk peserta didik menjadi pribadi utuh, yang memiliki norma-norma kehidupan sebagai makhluk individu maupun makhluk sosial (anggota masyarakat), baik sebagai warga negara Indonesia maupun sebagai warga dunia. Program normatif diberikan agar peserta didik bisa hidup dan berkembang selaras dalam kehidupan pribadi, sosial, dan bernegara. Program ini berisi mata pelajaran yang lebih menitikberatkan pada norma, sikap, dan perilaku yang harus diajarkan, ditanamkan, dan dilatihkan pada peserta didik, di samping kandungan pengetahuan dan keterampilan yang ada di dalamnya.

Program adaptif berfungsi membentuk peserta didik sebagai individu agar memiliki dasar pengetahuan yang luas dan kuat untuk menyesuaikan diri atau beradaptasi dengan perubahan yang terjadi di lingkungan sosial, lingkungan kerja, serta mampu mengembangkan diri sesuai dengan perkembangan ilmu pengetahuan, teknologi, dan seni. Program adaptif berisi mata pelajaran yang lebih menitikberatkan pada pemberian kesem- patan kepada peserta didik untuk memahami dan menguasai konsep dan prinsip dasar ilmu dan teknologi yang dapat diterapkan pada kehidupan sehari-hari dan atau melandasi kompetensi untuk bekerja. Program adaptif diberikan agar peserta didik tidak hanya memahami dan menguasai "apa" dan "bagaimana" suatu pekerjaan dilakukan, tetapi memberi juga pemahaman dan penguasaan tentang "mengapa" hal tersebut harus dilakukan.

Program produktif berfungsi membekali peserta didik agar memiliki kompetensi kerja sesuai standar Kompetensi Kerja Nasional Indonesia (SKKNI). Dalam hal SKKNI belum ada, maka digunakan standar kompetensi yang disepakati oleh forum yang dianggap mewakili dunia usaha/industri atau asosiasi profesi. Program produktif bersifat melayani permintaan pasar kerja, karena itu lebih banyak ditentukan oleh dunia usaha/industri atau asosiasi profesi. Program produktif diajarkan secara spesifik sesuai dengan kebutuhan tiap program keahlian.

Menurut Charlie (2002:3), pendidikan karakter merupakan upaya membantu peserta didik memahami, peduli, dan berperilaku sesuai nilai-nilai etika yang berlaku di masyarakat. Lebih lanjut dijelaskan bahwa pendidikan karakter adalah segala sesuatu yang dilakukan guru, yang mampu mempengaruhi karakter peserta didik. Guru membantu membentuk watak peserta didik. Hal ini mencakup keteladanan bagaimana perilaku gu$\mathrm{ru}$, cara guru berbicara atau menyampaikan materi, bagaimana guru bertoleransi, dan berbagai hal terkait lainnya. Menurut Ramli (2001:3), pendidikan karakter memiliki esensi dan makna yang sama dengan pendidikan moral dan pendidikan 
akhlak. Tujuannya adalah membentuk pribadi anak, supaya menjadi manusia yang baik, warga masyarakat, dan warga negara yang baik. Adapun kriterianya adalah nilai-nilai sosial tertentu yang banyak dipengaruhi oleh budaya masyarakat dan bangsanya. Oleh karena itu, hakikat dari pendidikan karakter dalam konteks pendidikan di Indonesia adalah pedidikan nilai, yakni pendidikan nilainilai luhur yang bersumber dari budaya bangsa Indonesia sendiri, dalam rangka membina kepribadian generasi muda.

Beberapa ciri orang yang memiliki karakter menurut Kirschenbaum (1995: 21-23) antara lain: hormat, tanggung jawab, peduli, disiplin, loyal, berani, dan toleran. Seseorang yang berkarakter mulia memiliki pengetahuan tentang potensi dirinya, yang ditandai dengan nilai-nilai seperti percaya diri, rasional, logis, kritis, analitis, kreatif dan inovatif, mandiri, hidup sehat, bertanggung jawab, sabar, berhati-hati, rela berkorban, pemberani, dapat dipercaya, jujur, menepati janji, adil, rendah hati, ramah, cinta keindahan (estetis), sportif, dan tabah. Individu juga memiliki kesadaran untuk berbuat yang terbaik atau unggul, dan bertindak sesuai potensi dan kesadarannya. Individu yang berkarakter baik atau unggul adalah seseorang yang berusaha melakukan halhal yang terbaik terhadap Tuhan YME, dirinya, sesama, lingkungan, bangsa dan negara serta dunia internasional pada umumnya dengan mengoptimalkan potensi (pengetahuan) dirinya dan disertai dengan kesadaran, emosi dan motivasinya (perasaannya).

Tujuan pendidikan karakter pada dasarnya adalah mendorong lahirnya anakanak yang baik (insan kamil). Tumbuh dan berkembangnya karakter yang baik akan mendorong peserta didik tumbuh dengan kapasitas dan komitmennya untuk melakukan berbagai hal yang terbaik dan melakukan segalanya dengan benar serta memiliki tujuan hidup. Masyarakat juga berperan membentuk karakter anak melalui orang tua dan lingkungannya.

Karakter dikembangkan melalui tahap pengetahuan, pelaksanaan, dan kebiasaan (Kemendiknas, 2010:16). Karakter tidak terbatas pada pengetahuan saja. Seseorang yang memiliki pengetahuan kebaikan belum tentu mampu bertindak sesuai dengan pengetahuannya, jika tidak terlatih (menjadi kebiasaan) untuk melakukan kebaikan tersebut. Karakter juga menjangkau wilayah emosi dan kebiasaan diri. Menurut Lickona (1991:53) diperlukan tiga komponen karakter yang baik (components of good character), yaitu moral knowing (pengetahuan tentang moral), moral feeling atau perasaan (penguatan emosi) tentang moral, dan moral action atau perbuatan bermoral. Hal ini diperlukan agar peserta didik dan atau warga sekolah lain yang terlibat dalam sistem pendidikan tersebut sekaligus dapat memahami, merasakan, menghayati, dan mengamalkannilai-nilaikebajikan (moral).

Dimensi-dimensi yang termasuk dalam moral knowing yang akan mengisi ranah kognitif adalah kesadaran moral (moral awareness), pengetahuan tentang nilainilai moral (knowing moral values), penentuan sudut pandang (perspective taking), logika moral (moral reasoning), keberanian mengambil sikap (decision making), dan pengenalan diri (self knowledge). Moral feeling merupakan penguatan aspek emosi peserta didik untuk menjadi manusia berkarakter. Penguatan ini berkaitan de- 
ngan bentuk-bentuk sikap yang harus dirasakan oleh peserta didik, yaitu kesadaran akan jati diri (conscience), percaya diri (self esteem), kepekaan terhadap derita orang lain (emphaty), cinta kebenaran (loving the good), pengendalian diri (self control), kerendahan hati (humility). Moral action merupakan perbuatan atau tindakan moral yang merupakan hasil (outcome) dari dua komponen karakter lainnya. Untuk memahami apa yang mendorong seseorang dalam perbuatan yang baik (act morally), maka harus dilihat tiga aspek lain dari karakter yaitu kompetensi (competence), keinginan (will), dan kebiasaan (habit).

Pengembangan karakter di sekolah sementara ini direalisasikan dalam pelajaran agama, pelajaran kewarganegaraan, atau pelajaran lainnya, yang program utamanya cenderung pada pengenalan nilai-nilai secara kognitif, dan mendalam sedikit sampai ke penghayatan nilai secara afektif. Menurut Buchori (2007:3), pengembangan karakter seharusnya membawa anak ke pengenalan nilai secara kognitif, penghayatan nilai secara afektif, akhirnya ke pengamalan nilai secara nyata. Untuk sampai ke praksis, ada satu peristiwa batin yang amat penting yang harus terjadi dalam diri anak, yaitu munculnya keinginan yang sangat kuat (tekad) untuk mengamalkan nilai. Peristiwa ini disebut Conatio, dan langkah untuk membimbing anak membulatkan tekad ini disebut langkah konatif. Pendidikan karakter mestinya mengikuti langkahlangkah yang sistematis, dimulai dari pengenalan nilai secara kognitif, langkah memahami dan menghayati nilai secara afektif, dan langkah pembentukan tekad secara konatif. Ki Hajar Dewantoro men- terjemahkannya dengan kata-kata cipta, rasa, karsa.

Pada dasarnya penyelenggaraan pendidikan karakter di sekolah dapat dilakukan secara terpadu pada setiap kegiatan sekolah. Setiap aktivitas peserta didik di sekolah dapat digunakan sebagai media untuk menanamkan karakter, mengembangkan konasi, dan memfasilitasi peserta didikberperilaku sesuai nilai-nilai yang berlaku. Setidaknya, terdapat dua jalur utama dalam menyelenggarakan pendidikan karakter di sekolah, yaitu (1) terpadu melalui kegiatan Pembelajaran; dan (2) terpadu melalui kegiatan ekstrakurikuler.

Pendidikan karakter secara terpadu di dalam pembelajaran adalah pengenalan nilai-nilai, fasilitasi diperolehnya kesadaran akan pentingnya nilai-nilai, dan penginternalisasian nilai-nilai ke dalam tingkah laku peserta didik sehari-hari melalui proses pembelajaran, baik yang berlangsung di dalam maupun di luar kelas pada semua mata pelajaran. Pada dasarnya kegiatan pembelajaran, selain untuk menjadikan peserta didik menguasai kompetensi (materi) yang ditargetkan, juga dirancang untuk menjadikan peserta didik mengenal, menyadari/peduli, dan menginternalisasi nilai-nilai dan menjadikannya perilaku. Dalam struktur kurikulum SMK, pada dasarnya setiap mata pelajaran memuat materi-materi yang berkaitan dengan karakter. Integrasi pendidikan karakter pada mata-mata pelajaran di sekolah mengarah pada internalisasi nilai-nilai di dalam tingkah laku seharihari melalui proses pembelajaran dari tahapan perencanaan, pelaksanaan, dan penilaian. 
Pendidikan karakter melalui kegiatan ekstra kurikuler dipandang sangat relevan dan efektif. Nilai-nilai karakter seperti kemandirian, kerjasama, sabar, empati, cermat dan lainya dapat diinternalisasikan dan direalisasikan dalam setiap kegiatan ekstra kurikuler. Ekstrakurikuler dapat diartikan sebagai kegiatan pendidikan yang dilakukan di luar jam pelajaran tatap muka. Kegiatan tersebut dilaksanakan di dalam sekolah dan/atau di luar lingkungan sekolah dalam rangka memperluas pengetahuan, meningkatkan keterampilan, dan menginternalisasi nilai-nilai atau aturan-aturan agama serta norma-norma sosial baik lokal, nasional, maupun global untuk membentuk insan yang paripurna. Dengan kata lain, ekstrakurikuler merupakan kegiatan pendidikan di luar jam pelajaran yang ditujukan untuk membantu perkembangan peserta didik, sesuai dengan kebutuhan, potensi, bakat, dan minat mereka melalui kegiatan yang secara khusus diselenggarakan oleh pendidik dan atau tenaga kependidikan yang berkemampuan dan berkewenangan di sekolah.

Beberapa kegiatan ekstra kurikuler di SMK yang memuat pembentukan karakter antara lain: olahraga (sepak bola, bola voli, bulu tangkis, tenis meja, dan lainlain); keagamaan (baca tulis Al Qur'an, kajian hadis, ibadah, dan lain-lain); seni budaya (menari, menyanyi, melukis, teater), KIR, Kepramukaan, Latihan Dasar Kepemimpinan Peserta Didik (LDKS), Palang Merah Remaja (PMR), Pasukan Pengibar Bendera Pusaka (PASKIBRAKA), Pameran, Lokakarya, Kesehatan, dan lain-lainnya (Kemendiknas, 2010:28).

\section{PENILAIAN PENDIDIKAN KARAK- TER}

Penilaian karakter merupakan tahapan yang sangat penting sekaligus rumit. Hal ini berkenaan dengan hasil akhir dari pendidikan karakter yang berupa tindakan moral. Hasil pendidikan karakter bukan hanya berupa pemikiran atau gerakan yang dengan mudah dapat dinilai melalui kemampuan menulis jawaban, atau mempraktekkan sebuah keterampilan yang kemudian diakumulasikan dalam bentuk angka. Penilaian karakter berkaitan dengan perilaku peserta didik dalam setiap aktivitas baik di lingkungan sekolah maupun di luar sekolah.

Terdapat tiga istilah yang terkait untuk mengetahui hasil pendidikan karakter, yaitu pengukuran, penilaian, dan pengambilan keputusan. Ketiganya memiliki batasan pengertian yang sedikit berbeda dan saling terkait. Pengukuran merupakan suatu proses penentuan tentang derajat atau seberapa besar karakteristik yang dimiliki oleh individu (Shute and Becker, 2010:5-7). Pengukuran adalah suatu proses kegiatan untuk mengukur, membandingkan sesuatu, dapat berupa karakteristik, watak atau kemampuan peserta didik atas dasar ukuran tertentu. Mengukur dimaksudkan memberi bentuk kuantitatif dari suatu karakteristik atau kemampuan yang dimiliki peserta didik dalam bentuk angka. Secara ringkas pengukuran merupakan suatu kegiatan untuk mendapatkan informasi atau data secara kuantitatif. Penilaian seringkali disamakan dengan istilah 'evaluasi', yaitu suatu proses sistematis dalam mengumpulkan, menganalisa, dan menginterpretasikan informasi yang umumnya diperoleh melalui pengukuran untuk me- 
ngetahui tingkat keberhasilan dan efisiensi suatu program pendidikan. Penilaian cenderung bersifat kualitatif.

Pengambilan keputusan atau kebijakan adalah tindakan yang diambil oleh seseorang atau lembaga berdasarkan data atau informasi yang telah diperoleh. Keputusan atau kebijakan yang baik memerlukan hasil penilaian yang baik, adapun penilaian pada umumnya memerlukan pengukuran. Di dalam pendidikan karakter, guru memerlukan berbagai informasi atau data yang sangat diperlukan dalam mengambil keputusan, untuk menyusun program dan menyempurnakan pelaksanaan pendidikan karakter. Apabila pengambilan keputusan dilakukan berdasarkan pada informasi yang akurat dan dapat diandalkan, penyusunan dan penyempurnaan pendidikan karakter akan tepat sehingga dapat mengarah pada pencapaian hasil seperti yang diharapkan. Jika dilakukan sebaliknya, perancangan dan penyempurnaan pendidikan karakter akan tidak sesuai sehingga tidak akan efektif serta tidak dapat mencapai hasil sesuai yang direncanakan.

Secara umum, penilaian pendidikan karakter bertujuan untuk memperoleh informasi yang akurat tentang efektivitas pendidikan karakter, yang dapat digunakan untuk membuat keputusan-keputusan yang menyangkut siswa, memberikan umpan balik kepada siswa mengenai kemajuan karakternya, kelemahan, dan keunggulannya, menentukan kesesuaian materi, serta memberikan informasi untuk pembuatan kebijakan.

Dilihat dari subjek atau sasarannya, penilaian pendidikan karakter mencakup penilaian karakter pada siswa, pimpinan, guru dan karyawan, serta sekolah seba- gai institusi yang mengarah pada budaya sekolah (Roxanna, 2011:2). Penilaian karakter siswa bertujuan untuk menjawab pertanyaan sejauh mana siswa memahami dan komitmen terhadap nilai-nilai inti etika. Pada tahap ini sekolah dapat mengumpulkan data tentang berbagai karakter yang berhubungan dengan perilaku, antara lain: religius, percaya diri, rasional, mandiri, hidup sehat, bertanggung jawab, cinta ilmu, sabar, dapat dipercaya, jujur, menepati janji, adil, rendah hati, malu berbuat salah, pemaaf, berhati lembut, setia, bekerja keras, tekun, ulet/gigih, teliti, berinisiatif, berpikir positif, disiplin, bersahaja, bersemangat, dinamis, hemat/efisien, menghargai waktu, pengabdian/dedikatif, pengendalian diri, produktif, ramah, cinta keindahan (estetis), sportif, tabah, terbuka, dan tertib.

Penilaian karyawan sekolah sebagai pendidik karakter berangkat dari pertanyaan: sejauh mana staf sekolah, pengajar, tenaga administrasi, dan dukunganpersonillainnya mengembangkan pemahaman tentang apa yang mereka dapat lakukan untuk mendorong pengembangan karakter? Sejauh mana komitmen pribadi untuk melakukan hal tersebut? Sejauh mana kemampuan untuk melaksanakannya? Sejauh mana kebiasaan bertindak yang konsisten atas kapasitas pengembangan mereka sebagai pendidik karakter? Pada tataran ini, yang dinilai adalah keteladanan seluruh komponen sekolah selain siswa (www.inilahguru.com, diunduh 14 Maret 2011).

Pada tataran karakter sekolah penilaian dilakukan untuk mengetahui sejauhmana budaya sekolah telah berkembang dan memiliki karakter sebagai sekolah yang berprestasi dan menjadi idola ma- 
syarakat. Hal ini dapat dinilai, misalnya, dengan survei yang meminta siswa untuk menunjukkan sejauh mana mereka setuju dengan pernyataan seperti, "Sekolah (kelas) ini adalah seperti sebuah keluarga, suasananya nyaman, kondusif, dan memiliki reputasi yang baik di masyarakat".

Pada dasarnya, tidak ada benar atau salah di dalam strategi penilaian. Persoalannya adalah bagaimana kita dapat memilih suatu cara penilaian yang tepat dan dapat menentukan mengenai apa yang siswa ketahui dan apa yang dapat dilakukannya. Berbagai alat ukur atau strategi hanya dapat dikatakan baik dengan melihat sejauh mana keterkaitannya dengan tujuan dan dampak nyata (outcome) yang diharapkan dari suatu materi pelajaran.

Karakter merupakanbagian dari kompetensi yang harus dikuasai siswa. Kompetensi terdiri atas tiga ranah yang saling berkaitan, yaitu kognisi, keterampilan, dan afeksi. Afeksi sangat berkaitan dengan karakter atau nilai-nilai yang melandasi seseorang untuk berperilaku. Penilaian karakter dapat dilakukan terpadu dengan penilaian kompetensi siswa dengan mengacu pada standar kompetensi lulusan. Namun demikian, mengingat demikian pentingnya makna karakter pada diri siswa maka penilaian karakter perlu dilakukan juga secara khusus di luar penilaian yang terpadu dengan kompetensi yang dilakukan guru pada masing-masing mata pelajaran.

Sesuai dengan Peraturan Menteri Pendidikan Nasional No. 20 Tahun 2007 tentang Standar Penilaian Pendidikan, penilaian hasil belajar pada jenjang pendidikan dasar dan menengah dilaksanakan oleh pendidik, satuan pendidikan, dan pemerintah. Pelaksanaan penilaian oleh pendidik yang berkaitan dengan kompetensi pada masing-masing mata pelajaran dilakukan menggunakan strategi penilaian kelas. Penilaian kelas didefinisikan sebagai suatu penilaian berkelanjutan yang dirancang, dilaksanakan, dan hasilnya dimanfaatkan oleh guru dan siswa untuk mengoptimalkan efektivitas pembelajaran di kelas (Duncan and Chris, 1994:38). Penilaian kelas dirancang dan dilaksanakan oleh masing-masing guru sesuai mata pelajarannya. Hampir senada dengan pendapat tersebut, Pusat Kurikulum Depdiknas (2006:43) menyatakan bahwa penilaian kelas merupakan bagian dari penilaian internal yang digunakan untuk menilai tingkat pencapaian kompetensi siswa yang dilaksanakan pada saat pembelajaran berlangsung dan akhir pembelajaran. Penilaian kelas dirancang untuk membantu para guru dalam memperoleh informasi yang akurat tentang apa yang dipelajari siswa, dan sejauhmana mereka berhasil menguasai materi pembelajaran. Penilaian kelas memiliki setidaknya tujuh ciri, yaitu: berpusat pada siswa, otonomi Guru, bermanfaatganda, formatif, kontekstual, dan berkelanjutan.

Penilaian kelas, terutama memusatkan perhatian pada siswa, yaitu mengamati kegiatan dan kemajuan belajar serta membantu siswa untuk menguasai substansi pelajaran dan mengembangkan karakter. Partisipasi aktif dari siswa dalam penilaian sangat ditekankan. Keterlibatan siswa dalam penilaian lebih memungkinkan siswa untuk melakukan self assessment (penilaian sendiri) terhadap substansi yang dipelajari. Di samping itu, siswa memahami bahwa penilaian kelas ter- 
sebut untuk kepentingan bersama antara guru dan siswa. Berdasarkan hasil penilaian tersebut, guru akan membantu bagaimana agarpara siswa dapat belajar dengan lebih baik. Hal ini akan meningkatkan motivasi siswa untuk mengikuti penilaiandan memanfaatkan hasilnya untuk belajar dengan lebih giat dan mengembangkan karakter.

Penilaian kelas menekankan pada kegiatan pembelajaran di kelas sehingga beberapa jenis penilaian dapat dilakukan. Berdasarkan sifat dan pendekatannya, jenis penilaian dibedakan menjadi penilaian formaldan informal (Angelo and Cross, 1993). Penilaian informal merupakan penilaian yang rancangan dan pelaksanaannya kurang terstruktur, tidak secara khusus disusun secara sistematis oleh guru. Penilaian ini cenderung bersifat formatif dan kualitatif, dilakukan oleh guru secara terus-menerus selama pembelajaran tanpa menggunakan instrumen penilaian baku. Guru sebagai life instrument mengamati kegiatan siswa selama pembelajaran, memantau kemajuan belajar, memeriksa tugas-tugas (pekerjaan rumah), memberikan tanggapan terhadap pertanyaan siswa, dan kegiatan penilaian lain selama pembelajaran. Melalui penilaian informal memungkinkan siswa dapat mendemonstrasikan apa yang diketahui dalam situasi yang nyaman, dan guru dapat melihat dan mendokumentasikan kemajuan belajar siswa, termasuk perkembangan karakternya. Penilaian formal merupakan penilaian yang rancangan dan pelaksanaannya disusun secara terstruktur dan sistematis oleh Guru, dengan menggunakan instrumen penilaian yang disusun secara ketat.
Beberapa teknik yang dapat digunakan dalam penilaian karakter antara lain observasi atau pengamatan, penilaian diri, tes (tanya jawab), dan diskusi. Pengamatan dilakukan terhadap kegiatan siswa secara terus-menerus selama berlangsungnya pembelajaran. Guru melakukan pengamatan terhadap siswa pada saat mereka membaca, bekerjasama dengan teman lainnya, mengerjakan tugas-tugas, memecahkan masalah, dan kegiatan lainnya. Pengamatan dapat dilakukan dengan menggunakan lembar pengamatan atau tanpa lembar pengamatan. Siswa diberi kesempatan untuk menilai kemajuan belajarnya melalui buku atau catatan yang secara khusus digunakan untuk mencatat kemajuan belajar, kesulitan, dan berbagai saran yang terkait dengan penyelenggaraan pembelajaran. Penilaian diri tidak terkait dengan pemberian nilai penguasaan atau prestasi belajar. Penjelasan penilaian diri yang ada dalam buku siswa memberikan umpan balik kepada guru sebagai masukan untuk membantu siswa dalam belajar dan mengembangkan karakternya.

Tanya jawab dilakukan untuk mengetahui sejauhmana siswa memahami substansi pelajaran, termasuk nilai-nilai karakter yang berkaitan dengan materi pelajaran tersebut. Tanya jawab hendaknya bersifat informal, terbuka, dan mendorong serta memotivasi siswa untuk belajar lebih giat. Diskusi di antara siswa dilakukan untuk mengetahui sejauhmana siswa memahami konsep atau menggunakan berbagai konsep untuk memecahkan suatu masalah sesuai dengan nilai-nilai etika, ilmiah dan moral. Melalui diskusi, guru dapat mengamati dan memperoleh informasi yang terkait de- 
ngan penguasaan siswa terhadap substansi pelajaran, termasuk perkembangan perilaku setiap siswa, seperti kerjasama, sopan santun, menghargai pendapat orang lain, dan sebagainya.

Penilaian kelas dilakukan terpadu dengan kegiatan pembelajaran. Dalam hal ini, penilaian dilakukan sebelum pembelajaran, pada saat pembelajaran, dan setelah selesai pembelajaran. Langkah awal dalam penilaian kelas adalah mengidentifikasi indikator pencapaian hasil belajar, termasuk nilai-nilai karakter dari mata pelajaran yang telah dikembangkan dalam silabus. Agar materi dalam silabus dapat dilaksanakan dalam pembelajaran, guru menjabarkan silabus menjadi rencana pelaksanaan pembelajaran (RPP). RPP adalah penjabaran silabus yang menggambarkan rencana prosedur dan pengorganisasian pembelajaran untuk mencapai kompetensi dasar yang ditetapkan dalam Standar Isi. RPP digunakan sebagai pedoman guru dalam melaksanakan pembelajaran dan penilaian baik di kelas, laboratorium, dan/atau lapangan. Sesuai dengan pendekatan penilaian yang digunakan, perlu mengembangkan instrumen penilaian. Meskipun Guru sebagai life instrument, namun instrumen seperti pedoman pengamatan, daftar periksa (check list), tes tertulis dan lain-lainnya perlu disiapkan dengan baik. Hal ini dapat digunakan oleh guru sebagai pedoman yang akan mempermudah melaksanakan penilaian dalam pembelajaran.

Sebelum pembelajaran, guru melakukan penilaian awal berkaitan dengan kesesuaian pembelajaran dengan siswa, antara lain kemampuan awal yang disyaratkan, penguasaan terhadap materi, minat dan motivasi belajar siswa. Penilaian ini dilakukan melalui pemeriksaan hasil pekerjaan rumah, secara informal memberikan pertanyaan-pertanyaan baik berkaitan dengan materi maupun motivasi belajar siswa, dan mengamati respon siswa. Temuan yang diperoleh dapat digunakan untuk: mengembangkan rancangan remedi atau pengayaan, menjelaskan lagi materi yang dipandang sesuai dan mendukung karakter, menyesuaikan tempo (kecepatan) penyampaian materi.

Kegiatan guru dalam penilaian kelas selama pembelajaran antara lain meliputi: menyesuaikan pendekatan pembelajaran sesuai temuan pada penilaian awal, memantau kegiatan belajar siswa, berkomunikasi dengan siswa untuk mengetahui sejauhmanamereka memahami apa yang sedang dipelajari, memperhatikan tanggapan siswa selama proses pembelajaran berlangsung dan memberikan penjelasan jika diperlukan, mengidentifikasi kemajuan belajar dan karakter siswa

Kegiatan guru setelah selesai melaksanakan kegiatan pembelajaran antara lain meliputi: memberikan kesempatan pada siswa untuk melakukan penilaian diri, mencakup kemajuan belajar, karakter, kesulitan, bantuan yang diperlukan untuk menguasai pelajaran, dan saransaran lainnya. Guru memberikan tugas terstruktur kepada siswa, dapat berupa pekerjaan rumah, tugas proyek, dan tugas lain yang sistematis dan terkait erat dengan substansi pelajaran dan karakter. Guru menganalisis informasi penilaian yang diperoleh sebelum dan selama pembelajaran untuk memahami perkembangan karakter setiap siswa, kemajuan belajar, dan memberikan informasiuntuk rancangan pembelajaran selanjutnya. Guru menjelaskan sejauhmana tujuan pembe- 
lajaran, termasuk pengembangan karakter yang telah dicapai siswa. Selian itu, guru juga mencatat dan melaporkan hasil-hasil penilaian untuk analisis, evaluasi dan pembuatan keputusan di tingkat sekolah, dan mengkomunikasikan berbagai keunggulan dan kelemahan berdasarkan pada hasil-hasil penilaian kepada siswa dan orang tua.

Di samping penilaian kelas yang dilakukan guru pada masing-masing mata pelajaran, penilaian karakter siswa perlu dilakukan secara khusus. Hal ini bertujuan untuk memperoleh informasi yang lebih lengkap dan komprehensif mengenai perkembangan karakter siswa dari waktu ke waktu. Penilaian karakter siswa perlu dilakukan secara khusus oleh wali kelas, guru Pendidikan Agama, dan guru Pendidikan Kewarganegaraan (PKn).

Wali kelas perlu merancang dan melaksanakan penilaian karakter secara berkelanjutan (on going assessment) terhadap para siswa yang menjadi tanggungjawabnya. Pengamatan tentang perkembangan karakter siswa harus dilakukan, termasuk melakukan teknik sosiometri atau peer assessment untuk mengetahui karakter siswa berdasarkan penilaian temanteman dalam satu kelas. Wali kelas juga perlu mengumpulkan informasi tentang karakter siswa dari setiap guru mata pelajaran. Setiap siswa sebaiknya memiliki buku catatan karakter yang disimpan wali kelas. Berdasarkan informasi dari berbagai pihak, termasuk hasil penilaian karakter yang dilakukan, wali kelas melakukan analisis dan kompilasi serta menyusun perkembangan karakter di setiap buku karakter siswa. Buku catatan karakter siswa dapat digunakan sebagai dasar pelaporan atau penilaian tentang kenaik- an kelas, kelulusan, atau keperluan terkait lainnya.

Guru Pendidikan Agama dan Guru PKn memliki tanggung jawab untuk melaksanakan pembelajaran dan penilaian karakter. Hal ini mengingat materi agama dan PKn sangat erat kaitannya dengan pembentukan karakter siswa. Penilaian kelas yang dilakukan pada mata pelajaran tersebut hendaknya tidak sekedar pada aspek pengetahuan dan keterampilan, namun lebih menekankan pada realisasi perilaku dalam kehidupan sehari-hari. Koordinasi dengan wali kelas dan guru mata pelajaran lain perlu dilakukan guna menjaring informasi tentang perkembangan karakter siswa.

Penilaian karakter guru dan karyawan sekolah perlu dilakukan oleh tim internal atau penanggungjawab pendidikan karakter di sekolah. Tim internal ini perlu merancang dan melakukan penilaian karakter secara objektif. Indikator-indikator perlu diidentifikasi, dan instrumen dikembangkan sesuai teknik pengumpulan data. Observasi secara mendalam dan berkelanjutan, serta wawancara merupakan teknik yang tepat untuk mengetahui peran mereka dalam pendidikan karakter, keteladanan perilaku, dan kinerjadalam penyelenggaraan pendidikan karakter.

Hasil pendidikan karakter pada tingkatan sekolah mengarah pada budaya sekolah (school culture). Budaya sekolah merupakan sekumpulan nilai yang melandasi perilaku, tradisi, kebiasaan keseharian, dan simbol-simbol yang dipraktikkan oleh warga sekolah seperti kepala sekolah, guru, petugas administrasi, siswa, dan masyarakat sekitar sekolah. Budaya sekolah merupakan ciri khas, karakter 
atau watak, dan citra sekolah tersebut di masyarakat luas (Kusumah, 2009:3). Penilaian budaya sekolah sebaiknya dilakukan oleh tim eksternal. Dalam hal ini, Dinas Pendidikan Kabupatean/Kota atau Propinsi perlu membentuk tim penilai pendidikan karakter sekolah. Tim ini antara lain beranggotakan pengawas sekolah, para ahli dari perguruan tinggi, dan praktisi bidang pendidikan. Tim internal pendidikan karakter di sekolah juga perlu melakukan penilaian atau monitoring dan evaluasi terhadap budaya sekolah sebagai umpan balik untuk menyempurnakan sistem pendidikan karakter di sekolah.

\section{PENUTUP}

Pendidikan karakter memiliki peran yang sangat penting dalam membangun karakter siswa. Siswa yang berkarakter memiliki keimanan dan ketaqwaan, kepedulian, kemandirian, keuletan, keingintahuan, kemampuan, dan motivasi yang tinggi untuk melakukan yang terbaik. Mereka akan lebih mampu dalam menghadapi berbagai tantangan hidup sehingga dapat meraih keberhasilan di masa mendatang. Pimpinan, guru dan karyawan sekolah harus menjadi teladan dalam berperilaku. Kesamaan persepsi dan tekad serta dukungan dari seluruh warga sekolah dalam penyelenggaraan pendidikan karakter sangat diperlukan agar dapat mencapai tujuan secara optimal. Penilaian yang komprehensif perlu dilakukan untuk mengetahui keberhasilan pendidikan karakter di sekolah. Penilaian kelas yang dilakukan oleh setiap guru mata pelajaran hendaknya mengintegrasikan nilai-nilai karakter yang sesuai dengan materi pelajaran tersebut. Wali ke- las secara khusus juga perlu melakukan penilaian karakter siswa dengan lebih intensif dan mendalam. Pada tingkatan sekolah, tim eksternal sangat diperlukan untuk melakukan penilaian sejauhmana sekolah telah memiliki budaya (school culture).

\section{UCAPAN TERIMA KASIH}

Terima kasih kepada Rektor dan pimpinan di lingkungan Fakultas Teknik Universitas Negeri Yogyakarta atas kesempatan yang diberikan kepada penulis untuk terlibat secara aktif dalam program pengembangan pendidikan karakter di Direktorat Jenderal Pendidikan Dasar Kementerian Pendidikan Nasional. Terima kasih juga disampaikan kepada tim Redaksi Jurnal Cakrawala Pendidikan atas masukkannya sehingga memungkinkan artikel ini dimuat di Cakrawala Pendidikan.

\section{DAFTAR PUSTAKA}

Angelo T.A, and Cross, P.K. 1993. Classroom Assessment Techniques. A Handbook for College Teachers (2nd Ed.). New York: Jossey-Bass.

Buchori, Mochtar. 2007. Character Building dan Pendidikan Kita. http:/wwww.kompas.co.id/kompas-cetak/0607/26/opini/2836169.htm. Diunduh 27 November 2010.

Charlie, Abourjilie. 2002. Character Education. North Carolina: Public School of North Carolina.

Departemen Pendidikan Nasional. 2008. Buku Bahan Bimbingan Teknik KTSP $S M K$. Jakarta: Direktorat Pembinaan SMK. 
Duncan, Harris and Chris, Bell. 1994. Evaluating and Assessing for Learning. New Jersey: Nichols Publishing Company.

Kementerian Pendidikan Nasional. 2010. Panduan Pendidikan Karakter. (Jakarta: Direktorat Pembinaan SMP).

Kirschenbaum, Howard. 1995. 100 Ways to Enhance Values and Morality in Schools and Youth Settings. Massachusetts: Allys \& Bacon.

Kusumah, Wijaya. 2009. Mengenalkan Budaya Sekolah Melalui MOS. http:// omjaylabs.wordpress.com. Diunduh 23 Juli 2009.

Lickona, Thomas. 1991. Educating for Character. New York: Bantam Books.

Marfu K. 2010. Penilaian Pendidikan Karakter. http://www.inilahguru.com/index.php?option=com_content\&vie w=article\&id. Diunduh 14 Maret 2011.

Peraturan Menteri Pendidikan Nasional No. 23 Tahun 2006. Standar Kompetensi Lulusan.

Peraturan Menteri Pendidikan Nasional No. 20 Tahun 2007. Standar Penilaian Pendidikan.

Peraturan Pemerintah No 19 tahun 2005. Standar Nasional Pendidikan.

Pusat Kurikulum. 2006. Penilaian Kelas. Jakarta: Depdiknas.
Rao, M.S. 2010. Which are the Employability Skills - Hard Skills or Soft Skills? http://www.career-journal.com/enMeadership /206.html? infoView $=254$ 55. Diunduh 31 Maret 2010.

Roxxana, Mechem. 2011. The Eleven Principles of Effective Character Education. Rockwood USA: National School of Character.

Ryan, Kevin, and Bohlin Karen E. 1999. Building Character in Schools. San Fransisco: John Willey \& Sons.

Shute, Valerie J, and Becker, Betsy Jane. 2010. Innovative Assessment for The $21^{\text {st }}$ Century. New York: Springer Science-Business Media.

Suyanto. 2009. Urgensi Pendidikan karakter. http://enewsletterdisdik.wordpress .com/2010/07/26/urgensi-pendidikan-karakter. Diunduh 28 November 2010.

Undang-Undang No 20 Tahun 2003 Tentang Sistem Pendidikan Nasional.

Zakaria, Teuku R. 2001. Pendekatan-Pendekatan Pendidikan Nilai dan Implementasidalam Pendidikan Budi Pekerti. http:/wwww.pdk.go.id /balitbang/Publikasi/Jurnal/No_026. Diunduh 27 November 2010. 